JP LPPM UNRI, ISSN: 2086-4779, e-ISSN: 2715-8209

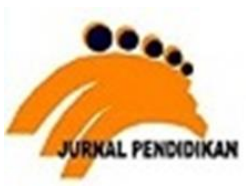

Jurnal Pendidikan

https://jp.ejournal.unri.ac.id/index.php/JP/index

\title{
PENGGUNAAN MODEL GI (GROUP INVESTIGATION) PADA PEMBELAJARAN PENDIDIKAN KEWARGANEGARAAN DI SEKOLAH DASAR
}

\author{
Rafhi Febryan Putera', Zahratul Qalbi ${ }^{2}$ \\ Universitas Negeri Padang ${ }^{1}$, Universitas Bengkulu ${ }^{2}$ \\ rafhifebryanputera@gmail.com
}

\begin{abstract}
This research is motivated by the initial reflection of researchers who conduct observation of teaching and learning activities in Paninjauan Elementary Schools elementary schools, that the civic education learning was dominated by the teacher using conventional learning method in learning low when the daily test exam and the final exam semeseter. The purpose of this study is to describe how learning planning, learning implementation, and learning outcomes. The approach used in this research is a qualitative approach and a quantitative approach with four stages, namely learning planning, learning implementation, learning observation, and learning reflection. The subjects used in this study were grade IV students of SDN 11 Paninjau Agam Regency. From the data analysis, it was found that the Group Investigation (GI) type of cooperative learning model was proven to improve student learning outcomes. This can be seen from the percentage of completeness learning Cycle I of 58.6 and in the second cycle increased to 72.25.
\end{abstract}

Keywords: Group Investigation, Civic Education, Learning Results

Abstrak: Penelitian ini dilatarbelakangi oleh refleksi awal peneliti yang melakukan obeservasi kegiatan belajar mengajar di Sekolah Dasar Paninjauan bahwa pembelajaran Pendidikan Kewarganegaraan masih didominasi oleh guru dengan menggunakan pembelajaran konvensional (ceramah) dalam pembelajaran, hal ini berdampak terhadap kualitas proses pembelajaran yang satu arah dan hasil belajar siswa yang rendah ketika ujian ulangan harian maupun ujian akhir semeseter. Tujuan dari penelitian ini adalah untuk mendeskripsikan bagaimana perencanaan pembelajaran, pelaksanaan pembelajaran, dan hasil belajar. Pendekatan yang digunakan dalam penelitian ini adalah pendekatan kualitatif dan pendekatan kuantitatif dengan empat tahap yaitu perencanaan pembelajaran, pelaksanaan pembelajaran, pengamatan pembelajaran, dan refleksi pembelajaran. Subjek yang digunakan dari penelitian ini adalah siswa kelas IV SDN 11 Paninjauan Kabupaten Agam. Dari analisis data yang dilakukan diperoleh bahwa model pembelajaran kooperatif tipe Group Investigation (GI) terbukti dapat meningkatkan hasil belajar siswa. Hal ini dapat dilihat dari persentase ketuntasan belajar Siklus I sebesar 58,6 dan pada siklus II meningkat menjadi sebesar 72,25

Kata kunci: Group Investigation, Pendidikan Kewarganegaraan, Hasil belajar 


\section{PENDAHULUAN}

Pendidikan Kewarganegaraan (PKn) merupakan salah satu mata pelajaran yang diajarkan di Sekolah dasar (SD). Sebagaimana yang dijelaskan oleh (Rachmadtullah 2015) bahwa "mata pelajaran Pendidikan Kewarganegaraan merupakan mata pelajaran yang memfokuskan pada pembentukan warga negara yang memahami dan mampu melaksanakan hak-hak dan kewajibannya untuk menjadi warganegara Indonesia yang cerdas, terampil, berkarakter yang diamanatkan oleh Pancasila dan UUD 1945". Hal ini menjadikan PKn sebagai mata pelajaran yang sangat penting dipelajari siswa. (Putera, dkk 2018) mengungkapakan Tujuan dan harapan guru dalam pembelajaran PKn adalah agar siswa dapat melakukan berbagai hal yang dituntut oleh kepatutan nilai moral serta mampu mengemukakan prilaku keteladanan yang lebih baik lagi (bagi masyarakat, Bangsa dan Negara).

Berdasarkan refleksi diri, yaitu pada saat peneliti menyajikan pembelajaran PKn di kelas IV SDN 11 Paninjauan pada tahun 2018, pembelajaran PKn belum terlaksana dengan baik. Pembelajaran berlangsung hanya menggunakan pendekatan konvensional saja, yaitu yang berperan aktif dalam pembelajaran adalah guru. Sedangkan siswa duduk mendengar dan mencatat saja. Hal ini sesua dengan yang di ungkapkan oleh (Marcelina, Melindawati, and Putera 2018) bahwa pembelajaran satu arah membuat pikiran siswa tidak tertantang untuk beraktivitas dan kreatifitas siswa sangat rendah dalam proses pembelajaran

Kurangnya keaktifan siswa selama pembelajaran berlangsung adalah disebabkan karena 1) guru sering menggunakan metode ceramah, sehingga menimbulkan rasa jenuh dan bosan pada siswa, 2) guru kurang memberikan kesempatan kepada siswa untuk berintegrasi dengan sesama teman kelompoknya, 3) guru kurang melibatkan siswa untuk dapat menemukan sendiri materi yang dipelajari, dimana siswa hanya menerima apa yang disampaikan oleh guru, 4) guru kurang memberikan kesempatan untuk bertanya jawab kepada siswa, sehingga kurang aktifnya siswa dalam pembelajaran, 5) pada pembelajaran siswa hanya menjadi objek sehingga kurang mendorong potensi yang dimiliki siswa untuk berkembang. Selain itu guru juga kurang merancang RPP yang tepat sehingga pembelajaran tidak berlangsung sesuai dengan apa yang diinginkan. Keadaan ini sangat berdampak pada hasil belajar yang diperoleh siswa.

Berdasarkan fenomena tersebut, peneliti merasa hal tersebut bukan semata-mata kesalahan siswa namun karena ketidaktepatan guru dalam merancang pembelajaran yang tepat. Salah satu solusinya adalah dengan memilih model pembelajaran yang tepat dalam pembelajaran maupun yang berdampak baik terhadap hasil belajar siswa.Model pembelajaran tersebut adalah model pembelajaran kooperatif tipe Group Investigation(GI). 
Trianto (Trianto 2014) mengemukakan bahwa "model pembelajaran kooperatif tipe Group Investigation menuntut siswa terlibat dalam perencanaan baik topik yang dipelajari dan bagaimana jalannya penyelidikan mereka".

Model pembelajaran GI dapat diterapkan dalam pembelajaran PKn (Hanurawan and Soetjipto 2009). Dengan menerapkan model GI diharapkan dapat mengubah pembelajaran dari yang berpusat pada guru menjadi berpusat pada siswa (Wicaksono, Sagita, and Nugroho 2017), sehingga siswa pun akan terlibat secara aktif dalam proses pembelajaran serta dapat memperoleh pemahaman dalam jangka waktu yang panjang, yang juga akan berimbas pada peningkatan hasil belajar siswa (Miaz 2014).

Berdasarkan permasalahan di atas, maka peneliti melakukan penelitian tidakan kelas yang berjudul "Penggunaan Model Pembelajaran Kooperatif Tipe Grouplnvestigation (GI) Untuk Meningkatkan Hasil Belajar Siswa Pada Pembelajaran Pendidikan Kewarganegaraan (PKn) di Kelas IV SDN 11 Paninjauan".

Secara umum tujuan penelitian ini untuk mendeskripsikan penggunaan model pembelajaran kooperatif tipe Group Investigation (GI) untuk meningkatkan hasil belajar siswa pada pembelajaran pendidikan kewarganegaraan(PKn) di kelas IV SDN 11 Paninjauan. Secara khusus tujuan dari penelitian ini adalah untuk mendeskripsikan: 1. Rencana Pelaksanaan Pembelajaran (RPP) dengan menggunakan model pembelajaran kooperatif tipe Grouplnvestigation (GI) untuk meningkatkan hasil belajar siswa pada pembelajaran Pendidikan Kewarganegaraan (PKn) di kelas IV SDN 11 Paninjauan. 2. Pelaksanaan pembelajaran dengan menggunakan model pembelajaran kooperatif tipe Group Investigation (GI) untuk meningkatkan hasil belajar siswa pada pembelajaran Pendidikan Kewarganegaraan (PKn) di kelas IV SDN 11 Paninjauan. 3. Hasil belajar siswa pada pembelajaran Pendidikan Kewarganegaraan (PKn) dengan menggunakan model pembelajaran kooperatif tipe Group Investigation (GI) di kelas IV SDN 11 Paninjauan.

\section{METODE PENELITIAN}

Penelitian ini dilaksanakan di SDN 11 Paninjauan Kabupaten Agam, peneliti ingin memperbaiki proses pembelajaran PKn di kelas IV yang masih menggunakan model pembelajaran yang konvensional, pihak sekolah, baik kepala sekolah maupun guru-guru yang mengajar di sekolah ini bersedia menerima pembaharuan pembelajaran demi keberhasilan belajar siswa. Sebagai subjek dalam penelitian ini adalah guru dan siswa kelas IV, yang terdaftar pada semester II tahun ajaran 2018/2018, dengan jumlah siswanya 26 orang, 12 orang laki-laki dan 14 orang perempuan.Penelitian ini peneliti lakukan sebanyak 2 siklus, siklus I terdiri dari 2 kali pertemuan, 
dan siklus II terdiri dari 1 kali pertemuan (tatap muka) (Sugiyono 2016). Penelitian dilaksanakan pada tanggal 2 April 2018- 23 April 2018.

Pendekatan yang digunakan dalam penelitian ini adalah pendekatan kualitatif dan kuantitatif, karena data yang diperoleh dalam penelitian ini bukan sekedar data kualitatif tetapi juga data kuantitatif yang berasal dari data skor nilai tes atau hasil belajar siswa.Menurut (Arikunto, Suharsimi 2013) "Pendekatan kualitatif dapat memberikan data berupa informasi berbentuk kalimat yang memberikan gambaran tentang ekspresi siswa tentang tingkat pemahaman terhadap suatu mata pelajaran(kognitif), pandangan atau sikap siswa terhadap metode belajar yang baru (afektif), aktivitas siswa mengikuti pelajaran, perhatian, antusia dalam belajar, kepercayaan diri, motivasi belajari”.Sedangkan pendekatan kuantitatif menurut (Creswell 2016) “Model kuantitatif merupakan model keputusan yang menggunakan angka".Jenis penelitian yang digunakan adalah Penelitian Tindakan Kelas (Classroom Action Research) (Creswell 2018) yaitu suatu penelitian yang dikembangkan bersama-sama dengan teman sejawat untuk melakukan perbaikan terhadap kegiatan pembelajaran.(Arikunto, Suharsimi 2013) menjelaskan bahwa "PTK adalah penelitian tindakan yang dilakukan di kelas dengan tujuan memperbaiki/meningkatkan mutu praktik pembelajaran".Data penelitian ini dikumpulkan dengan menggunakan teknik observasi dan teknik tes.Dalam penelitian ini, instrument yang digunakan berupa lembar observasi dan lembar tes. Prosedur penelitian dilakukan melalui 4 tahap yaitu: perencanaan, pelaksanaan, pengamatan, dan refleksi.

\section{HASIL DAN PEMBAHASAN}

\section{Hasil Siklus I}

Siklus I dilaksanakan selama 2 kali pertemuan. Siklus I pertemuan 1 dilakukan pada hari Selasa tanggal 2 April 2018 dengan waktu 2 x 35 menit, dimulai pukul 07.30 s/d 08.40 WIB. Dan siklus I pertemuan 2 pada hari Senin 2 April 2018 dengan waktu 2 x 35 menit, dimulai pukul 07.30 s/d 08.40 WIB. Penelitian dilakukan sesuai dengan alur yang telah dibuat, yaitu: 1) perencanaan, pelaksanaan, pengamatan, dan refleksi. Hal tersebut dapat dideskripsikan sebagai berikut:

\section{Perencanaan}

Penerapan model GI dalam pembelajaran PKn dengan kompetensi dasar mengenal bentukbentuk keputusan bersama disusun dalam bentuk Rencana Pelaksanaan Pembelajaran (RPP) dan instrumen penunjang penelitian. Perencanaan ini disusun dan dikembangkan berdasarkan Kurikulum Tingkat Satuan Pendidikan (KTSP) pada mata pelajaran PKn kelas IV semester II. 
Perencanaan pembelajaran pada siklus I disajikan dalam waktu 2 x pertemuan yaitu 2 × 35 menit pada setiap pertemuan. Materi pembelajaran yang dilaksanakan pada siklus I adalah keputusan bersama dengan cara musyawarah mufakat dan pemungutan suara.

\section{Pelaksanaan}

Siklus I pertemuan 1 dilaksanakan pada hari Selasa tanggal 2 April 2018 dengan waktu 2 × 35 menit, dimulai pukul 07.30 s/d 08.40 WIB. Dan siklus I pertemuan 2 dilaksanakan pada hari Kamis tanggal 5 April 2018 dengan waktu 2 x 35 menit, dimulai pukul 07.30 s/d 08.40 WIB. Pelaksanaan proses pembelajaran ini adalah dengan menerapkan model Gl yang terdiri dari enam langkah, antara lain: mengidentifikasi topic dan mengatur murid ke dalam kelompok, merencanakan tugas yang akan dipelajari, melakukan investigasi, menyiapkan laporan akhir, mempresentasikan laporan akhir, dan evaluasi.

Pada langkah mengidentifikasi topic dan mengatur murid ke dalam kelompok guru menanamkan konsep kemudian menugasi siswa membaca buku sumber untuk mendapat pengetahuan awal tentang materi. Setelah itu siswa memberikan kontribusi dalam memilih topic yang akan mereka selidiki. Kemudian siswa duduk dalam kelompok yang telah dibagi guru. Pada langkah merencanakan tugas siswa membuat perencanaan tentang apa yang akan diselidiki dalam kelompok. Pada langkah melaksanakan investigasi para siswa mengumpulkan informasi dengan cara memberikan kontribusi masing-masing anggota kelompok. Pada langkah menyiapkan laporan akhir kelompok mulai menentukan pesan dari hasil kerja kelompoknya dan membuat perencanaan bagaimanan kelompok menyajikan laporan akhirnya. Pada langkah mempresentasikan laporan akhir siswa menyajikan hasil kerja kelompoknya dengan melibatkan seluruh pendengar.Pada langkah evaluasi siswa saling memberikan umpan balik mengenai topic yang dibahas dan siswa berkolaborasi dalam mengevaluasi pembelajaran.

\section{Pengamatan}

Pengamatan terhadap tindakan penerapan model Glpada pembelajaran PKn dilakukan bersamaan dengan pelaksanaan tindakan. Pengamatan dilakukan oleh teman sejawat yaitu guru kelas IV pada waktu pelaksanaan tindakan pembelajaran. Hasil pengamatan pada siklus I dilakukan pada aspek RPP, pelaksanaan (aspek guru dan aspek siswa), dan hasil belajar baik pertemuan 1 maupun pada pertemuan 2. berikut ini adalah hasil pengamatan selama siklus I: penilaian aspek RPP yaitu 91,06\%, penilaian aspek guru yaitu 83,75\%, penilaian aspek siswa yaitu $81,25 \%$, dan hasil belajar siswa yaitu 58,6. 


\section{Refleksi}

Berdasarkan hasil pengamatan dan hasil tes yang dilakukan, dapat disimpulkan bahwa hasil belajar siswa belum mencapai keberhasilan yang diharapkan. Dengan demikian penelitian dilanjutkan ke siklus II dengan harapan hasilnya lebih baik dari siklus I. Segala kekurangan yang muncul pada siklus I akan diperbaiki pada siklus II. Kekurangan tersebut diantaranya pembagian alokasi waktu yang kurang tepat sehingga siswa tergesa-gesa dalam melaksanakan kegiatan pembelajaran dan dalam menyelesaikan soal tes, guru kurang memberikan motivasi kepada siswa selama pembelajaran berlangsung, dan dalam bekerjasama dalam kelompok guru kurang memberikan bimbingan kepada siswa cara bekerjasama untuk mengerjakan tugas kelompok, sehingga saat siswa ditugasi dalam kelompok, banyak anggota kelompok yang tidak ikut serta, yang bekerja siswa yang pandai saja,. Dengan demikian upaya yang dilakukan pada siklus berikutnya adalah dengan mengurangi materi, terutama pada kegiatan inti, lebih banyak memberikan motivasi kepada siswa agar lebih aktif dalam belajar, dan sebelum siswa diberi tugas kelompok guru harus terlebih dahulu menyampaikan cara bekerjasama dalam mengerjakan tugas kelompok. Dengan demikian diharapkan pelaksanaan pembelajaran bentuk-bentuk keputusan bersama dengan model Gldapat berjalan dengan baik sebagaimana yang diharapkan, sehingga siswa mengalami peningkatan hasil belajar pada siklus berikutnya.

\section{Siklus II}

Siklus II dilaksanakan selama 1 kali pertemuan yaitu pada hari Senin tanggal 23 April 2018 dengan waktu 2 x 35 menit, dimulai pukul 07.30 s/d 08.40 WIB. Penelitian dilakukan sesuai dengan alur yang telah dibuat, yaitu: 1) perencanaan, pelaksanaan, pengamatan, dan refleksi. Hal tersebut dapat dideskripsikan sebagai berikut:

\section{Perencanaan}

Perencanaan pada siklus II merupakan kelanjutan dari kompetensi dasar siklus I dengan materi pembelajarannya tentang perbedaan antara musyawarah mufakat dengan pemungutan suara, dan kelebihan dan kekurangan dari musyawarah mufakat dan pemungutan suara.Penerapan model GI dalam pembelajaran PKndisusun dalam bentuk Rencana Pelaksanaan Pembelajaran (RPP) dan instrumen penunjang penelitian. Perencanaan pembelajaran pada siklus I disajikan dalam waktu 1 x pertemuan yaitu 2 × 35 menit.

\section{Pelaksanaan}

Siklus II dilaksanakan pada hari Senin tanggal 23 April 2018 dengan waktu 2 x 35 menit, dimulai pukul $07.30 \mathrm{~s} / \mathrm{d} 08.40$ WIB. Pelaksanaan proses pembelajaran ini adalah dengan 
menerapkan model Gl yang terdiri dari enam langkah, antara lain:mengidentifikasi topic dan mengatur murid ke dalam kelompok, merencanakan tugas yang akan dipelajari, melakukan investigasi, menyiapkan laporan akhir, mempresentasikan laporan akhir, dan evaluasi..

Pada langkah mengidentifikasi topic dan mengatur murid ke dalam kelompok guru menanamkan konsep kemudian menugasi siswa membaca buku sumber untuk mendapat pengetahuan awal tentang materi. Setelah itu siswa memberikan kontribusi dalam memilih topic yang akan mereka selidiki. Kemudian siswa duduk dalam kelompok yang telah dibagi guru. Pada langkah merencanakan tugas siswa membuat perencanaan tentang apa yang akan diselidiki dalam kelompok. Pada langkah melaksanakan investigasi para siswa mengumpulkan informasi dengan cara memberikan kontribusi masing-masing anggota kelompok. Pada langkah menyiapkan laporan akhir kelompok mulai menentukan pesan dari hasil kerja kelompoknya dan membuat perencanaan bagaimanan kelompok menyajikan laporan akhirnya. Pada langkah mempresentasikan laporan akhir siswa menyajikan hasil kerja kelompoknya dengan melibatkan seluruh pendengar.Pada langkah evaluasi siswa saling memberikan umpan balik mengenai topic yang dibahas dan siswa berkolaborasi dalam mengevaluasi pembelajaran.

\section{Pengamatan}

Pengamatan terhadap tindakan penerapan model GI pada pembelajaran PKn dilakukan bersamaan dengan pelaksanaan tindakan. Pengamatan dilakukan oleh teman sejawat yaitu guru kelas IV pada waktu pelaksanaan tindakan pembelajaran. Hasil pengamatan pada siklus II dilakukan pada aspek RPP, pelaksanaan (aspek guru dan aspek siswa), dan hasil belajar. Berikut ini adalah hasil pengamatan selama siklus II: penilaian aspek RPP yaitu 96,42\%, penilaian aspek guru yaitu $97,5 \%$, penilaian aspek siswa yaitu $97,5 \%$, dan hasil belajar siswa yaitu 72,25.

\section{Refleksi}

Berdasarkan hasil pengamatan dan hasil tes yang dilakukan, dapat disimpulkan bahwa hasil belajar siswa sudah mencapai keberhasilan yang diharapkan.Dengan demikian penelitian dihentikan di siklus II karena segala kekurangan-kekurangan yang muncul di siklus I sudah berhasil diperbaiki pada siklus II. 


\section{PEMBAHASAN}

\section{Pembahasan siklus I}

Rencana Pelaksanaan Pembejaran PKn dengan Menerapkan model GI

Rencana pelaksanaan pembelajaran ini dibuat sesuai dengan enam langkah penerapan model Glyang dikemukakan oleh Slavin (2008:218-220) yaitu “mengidentifikasi topic dan mengatur murid ke dalam kelompok, merencanakan tugas yang akan dipelajari, melakukan investigasi, menyiapkan laporan akhir, mempresentasikan laporan akhir, dan evaluasi."

Dalam merancang RPP langkah-langkah yang perlu dilakukan guru adalah memilih Standar kompetensi (SK), menentukan Kompetensi Dasar (KD), menentukan indicator pembelajaran, memilih materi yang sesuai dengan KD dan indicator, menentukan tujuan pembelajaran yang ingin dicapai, merancang proses oembelajaran, menentukan sumber, menentukan metode pembelajaran yang tepat, mempersiapkan alat dan media pembelajaran, dan menyusun evaluasi sesuai dengan indicator pembelajaran.

Dari hasil paparan data siklus I diketahui bahwa perencanaan pembelajaran dengan materi keputusan bersama dengan cara musyawarah mufakat dan pemungutan suara dapat dilakukan dengan baik, namun masih terdapat kekurangan-kekurangan.

Berdasarkan hasil penilaian RPP, dapat diketahui bahwa skor yang diperoleh dari hasil RPP siklus I yaitu 91,06\% yang merupakan kategori sangat baik dan masih harus ditingkatkan karena masih ada deskriptor yang belum muncul.

Pelaksanaan pembelajaran PKn dengan Menerapkan model GI

Pelaksanaan pembelajaran dengan menerapkan model Glpada siklus I menggunakan enam langkah dalam pembelajaran model Gl. Langkah-langkah kegiatan pembelajaran yang direncanakan untuk mencapai indikator pada kegiatan awal mengucapkan salam, menyiapkan kondisi kelas, mengajak siswa berdoa sebelum belajar, dan mengambil absen siswa. Kemudian menyiapkan siswa untuk siap belajar dengan cara mengadakan tanya jawab sebagai appersepsi dalam memulai pelajaran dan menyampaikan tujuan pembelajaran. Pada karakteristik appersepsi guru belum memberikan umpan balik terhadap jawaban siswa.

Sedangkan kegiatan inti untuk mencapai indikator adalah sesuai dengan langkah-langkah pembelajaran dengan menerapkan model GI menurut Slavin yaitu dengan menerapkan enam langkah model Glyang terdiri dari:Pada karakteristik mengidentifikasi topic dan mengatur murid ke dalam kelompok guru telah melakukan kegiatan pembelajaran dengan baik. Dimana guru sudah menjelaskan materi kepada siswa sehingga siswa dapat memiliki pengetahuan awal sebelum 
melanjutkan kepada kegiatan berikutnya.Pada karakteristik merencanakan tugas yang akan dipelajari guru belum mengarahkan tugas-tugas apa saja yang akan dilakukan masing-masing kelompok sehingga tujuan pembelajaran belum tercapai. Sebagaimana menurut Rusman (2010:56) "guru bertugas untuk mengarahkan kegiatan belajar siswa untuk mencapai tujuan pembelajaran".Pada karakteristik melaksanakan investigasi guru masih belum membimbing siswa melaksanakan investigasi dalam kelompok sehingga kelompok kesulitan dalam melakukan tugas yang diberikan oleh guru. Padahal dalam kegiatan ini siswa memerlukan bimbingan guru saat melaksanakan investigasi dalam kelompok. Sebagaimana menurut Isjoni (2009:63) "guru berperan dalam membimbing serta mengarahkan jalannya diskusi tapi tidak memberikan jawaban". Pada saat menyiapkan laporan akhir guru belum membimbing siswa menyimpulkan hasil diskusi kelompok padahal dalam kegiatan ini siswa memerlukan bimbingan guru agar dapat menyimpulkan hasil diskusi kelompok dengan benar. Sebagaimana menurut Isjoni (2009:63) "guru berperan sebagai penghubung dalam menjebatani mengaitkan materi pembelajaran yang sedang dibahas dengan permasalahan yang ditemukan". Pada saat mempresentasikan laporan akhir guru masih belum memotivasi siswa untuk menanggapi pendapat teman sehingga siswa menjadi pasif. Sebagaimana menurut Isjoni (2009:63) “ guru berperan sebagai pemberi semangat pada siswa untuk aktif berpartisipasi". Pada saat evaluasi guru belum memeriksa hasil kegiatan kelompok dan memperbaiki jika ada kesalahan. Hal ini dikarenakan kurangnya waktu yang tersedia saat proses pembelajaran berlangsung. Menurut Rusman (2010:6) "alokasi waktu ditentukan sesuai dengan keperluan untuk pencapaian kompetensi dasar dan beban belajar."

Berdasarkan hasil penilaian dari aspek guru, dapat diketahui bahwa skor yang diperoleh dari hasil penilaian dari aspek guru siklus I 83,75\% yang merupakan kategori sangat baik, skor yang diperoleh dari hasil penilaian dari aspek siswa siklus I 81,25\% yang merupakan kategori sangar baik. Tapi masih harus ditingkatkan karena masih ada deskriptor yang belum muncul.

Hasil belajar PKn dengan Menerapkan model GI

Untuk mengetahui hasil belajar siswa maka guru melakukan evaluasi terhadap siswa yang berkaitan dengan pembelajaran yang telah dilakukan. Dari analisis penelitian siklus I nilai rata-rata kelas pada tes siklus I pertemuan 1 adalah 67,83 dan belum mencapai KKM mata pelajaran PKn yang ditetapkan yaitu 75. Tes siklus I pertemuan 2 adalah 74,4 juga masih belum mencapai KKM. Sedangkan aspek afektif pada siklus I pertemuan 1 adalah 68,87 dan pertemuan 2 adalah 72,54. Aspek psikomotor siklus I pertemuan 1 adalah 68,87, dan pertemuan 2 adalah 76,71. Jumlah siswa yang tuntas pada siklus I pertemuan 1 adalah 5 orang dan siswa yang tidak tuntas mencapai 19 orang. Siswa yang tuntas pada pertemuan 2 sebanyak 11 orang, sedangkan siswa yang tidak tuntas 
sebanyak 13 orang. Jika dipresentasekan ketunasan siklus I pertemuan 1 belum mencapai 75\%, dimana ketuntasan siswa perorangan baru mencapai $25 \%$ dan presentase siswa yang tidak tuntas mencapai $75 \%$. Sedangkan pada pertemuan 2, ketuntasan siswa mencapai $46 \%$ dan siswa yang tidak tuntas mencapai 54\%. Maka direncanakan untuk melakukan perbaikan pada pembelajaran berikutnya atau perbaikan selama proses pembelajaran pada siklus II.

\section{Pembahasan siklus II}

Rencana Pelaksanaan Pembejaran PKn dengan Menerapkan model GI

Rencana pelaksanaan pembelajaran ini dibuat sesuai dengan enam langkah tujuh penerapan model GI yang dikemukakan oleh (Slavin 2015) yaitu "mengidentifikasi topic dan mengatur murid ke dalam kelompok, merencanakan tugas yang akan dipelajari, melakukan investigasi, menyiapkan laporan akhir, mempresentasikan laporan akhir, dan evaluasi."

Dalam merancang RPP langkah-langkah yang perlu dilakukan guru adalah memilih Standar kompetensi (SK), menentukan Kompetensi Dasar (KD), menentukan indicator pembelajaran, memilih materi yang sesuai dengan KD dan indicator, menentukan tujuan pembelajaran yang ingin dicapai, merancang proses oembelajaran, menentukan sumber, menentukan metode pembelajaran yang tepat, mempersiapkan alat dan media pembelajaran, dan menyusun evaluasi sesuai dengan indicator pembelajaran.

Dari hasil paparan data siklus II diketahui bahwa perencanaan pembelajaran dengan materi perbedaan antara musyawarah mufakat dengan pemungutan suara, dan kelebihan dan kekuranagan musyawarah mufakat dan pemungutan suara telah mengalami peningkatan dalam beberapa aspek penilaian. Perolehan skor yang diperoleh dari hasil RPP siklus II yaitu 96,42\% yang merupakan kategori sangat baik. Oleh karena itu kekurangan-kekurangan yang terdapat pada siklus I telah dapat diperbaiki pada siklus II ini sehingga RPP yang dirancang pada siklus II dapat dikatakan telah berhasil.

Pelaksanaan pembelajaran PKn dengan Menerapkan Model GI

Pelaksanaan pembelajaran dengan menerapkan model GI pada siklus II menggunakan enam langkah dalam pembelajaran. Selama pembelajaran berlangsung dengan menerapkan model GI guru telah melakukan perbaikan terutama dalam memberikan motivasi yang lebih banyak kepada siswa sehingga siswa lebih aktif dalam belajar.Dengan demikian pelaksanaan pembelajaran dengan model GI telah meningkat.

Berdasarkan hasil penilaian dari aspek guru, dapat diketahui bahwa skor yang diperoleh dari hasil penilaian dari aspek guru siklus II 97,5\% yang merupakan kategori sangat baik, skor yang 
diperoleh dari hasil penilaian dari aspek siswa siklus I 97,5\% yang merupakan kategori sangat baik. Hal ini membuktikan siklus II sudah berjalan dengan baik dan termasuk dalam kualifikasi sangat baik, sehingga pelaksanaan pada siklus II sudah dapat dikatakan berhasil.

Hasil belajar PKn dengan Menerapkan Pendekatan CTL

Untuk mengetahui hasil belajar siswa maka guru melakukan evaluasi terhadap siswa yang berkaitan dengan pembelajaran yang telah dilakukan. Dari analisis penelitian siklus II nilai rata-rata kelas pada tes siklus II adalah 72,25 dan sudah mencapai KKM mata pelajaran PKn yang ditetapkan yaitu 75. Sedangkan aspek afektif pada siklus II adalah 80,41. Aspek psikomotor siklus II adalah 80,95 . Jumlah siswa yang tuntas pada siklus II adalah 21 orang dan siswa yang tidak tuntas ada 3 orang. Jika dipresentasekan ketuntasan siklus II sudah mencapai 75\%, dimana ketuntasan siswa perorangan mencapai $88 \%$ dan presentase siswa yang tidak tuntas mencapai $12 \%$.

Berdasarkan catatan pada lembar observasi dan diskusi peneliti dengan observer, hasil belajar siswa pada pembelajaran PKn pada siklus II sudah mencapai nilai ketuntasan belajar yang ditetapkan.

\section{SIMPULAN DAN SARAN}

\section{Simpulan}

Berdasarkan paparan data dan hasil penelitian serta pembahasan di atas, maka dapat ditarik kesimpulan sebagai berikut:perencanaan pembelajaran untuk meningkatkan hasil belajar siswa pada pembelajaran PKn dengan menerapkan model Gl di kelas IV SDN 11 Paninjauan siklus I diperoleh nilai 91,06\% dengan kualifikasi sangat baik, hal ini juga di dukung dari hasil penelitian (Christina and Kristin 2016) bahwa penggunaan GI dengan tepat dapat meningkatkan hasil belajar siswa, selain itu (Ulia 2014) juga mengemukakan bahwa dengan GI dapat mengaktifkan interaksi sesama siswa. Semua kekurangan pada siklus I diperbaiki pada siklus II sehingga diperoleh nilai96,42\% dengan kualifikasi sangat baik. Dengan demikian terjadi peningkatan dari siklus I ke siklus II.

Pelaksanaan pembelajaran untuk meningkatkan hasil belajar siswa pada pembelajaran PKn dengan menerapkan model GI di kelas IV SDN 11 Paninjauan siklus I diperoleh nilaidari aspekguru $83,75 \%$ dan penilaian dari aspek siswa $81,25 \%$. Semua kekurangan pada siklus I tersebut diperbaiki pada siklus II sehingga penilaian dari aspek guru diperoleh rata-rata 97,5\% dan penilaian dari aspek siswa 97,5\%. Dengan demikian terjadi peningkatan dari siklus I ke siklus II. 
Hasil belajar siswa pada pembelajaran PKn dengan menerapkan model GI di kelas IV SDN 11 Paninjauan siklus I diperoleh nilai yaitu 58,6 dan mengalami peningkatan pada siklus II yaitu 72,25.

\section{Saran}

Berdasarkan kesimpulan di atas, maka peneliti mengajukan beberapa saran untuk dipertimbangkan, antara lain:Sebelum melaksanakan kegiatan belajar mengajar diharapkan guru membuat perencanaan yang matang sesuai dengan pendekatan pembelajaran yang akan diterapkan, dan memahami langkah-langkah pembelajaran yang aakan dilaksanakan.

Dalam pelaksanaan pembelajaran diharapkan guru mampu melaksanakan kegiatan belajar mengajar sesuai dengan rancangan yang sudah dibuat sebelumnya.Dalam menerapkan pembelajaran dengan menerapkan model GI guru harus benar-benar memahami langkahlangkahnya, dan dapat mengelola waktu semaksimal mungkin.

Bagi guru hendaknya pembelajaran dengan menerapkan model GI dapat dijadikan sebagai salah satu alternative dalam pembelajaran PKn karena mampu meningkatkan hasil belajar siswa dalam pembelajaran PKn. Agar hasil belajar yang diharapkan dapat meningkat, sebaiknya guru tidak hanya melakukan penilaian hasil saja, tetapi juga melakukan penilaian proses untuk melihat keaktifan dan kemampuan siswa dalam menemukan jawaban dari suatu pembelajaran yang sudah dirumuskan.

\section{DAFTAR PUSTAKA}

Arikunto, Suharsimi. (2013). Prosedur Penelitian : Suatu Pendekatan Praktik (Edisi Revisi).

Christina, Lucia Venda and Firosalia Kristin. (2016). "EFEKTIVITAS MODEL PEMBELAJARAN TIPE GROUP INVESTIGATION (GI) DAN COOPERATIVE INTEGRATED READING AND COMPOSITION (CIRC) DALAM MENINGKATKAN KREATIVITAS BERPIKIR KRITIS DAN HASIL BELAJAR IPS SISWA KELAS 4." Scholaria : Jurnal Pendidikan Dan Kebudayaan.

Creswell. (2018). "Pendekatan Kuantitatif Dan Kualitatif Mlxed." Health Services Management Research.

Creswell, John W. (2016). Research Design: Pendekatan Metode Kualitatif, Kuantitatif, Dan Campuran.

Hanurawan, Fattah and Budi Soetjipto. (2009). "Pengembangan Buku Panduan Guru Untuk Pembelajaran PKn SD/MI Melalui Berbagai Model Cooperative Learning." Jurnal Sains Psikologi.

Marcelina, Shella, Silfi Melindawati, and Rafhi Febryan Putera. (2018). "PENINGKATAN PROSES PEMBELAJARAN IPS MENGGUNAKAN MODEL KOOPERATIF TIPE TEAMS GAMES 
TOURNAMENT (TGT) DI KELAS IV SD NEGERI 05 ALANG RAMBAH KABUPATEN PESISIR SELATAN." JURNAL INOVASI PENDIDIKAN DAN PEMBELAJARAN SEKOLAH DASAR.

Miaz, Yalvema. (2014). Penelitian Tindakan Kelas Bagi Guru Dan Dosen.

Putera, Rafhi Febryan; Ladiva, Hasmai Bungsu; \& Anita, Yesi. (2018). PENINGKATAN HASIL BELAJAR SISWA PADA PEMBELAJARAN PENDIDIKAN KEWARGANEGARAAN (PKN) DENGAN MENGGUNAKAN MODEL JIGSAW DI SEKOLAH DASAR. Inovasi Pendidikan Dan Pembelajaran Di Sekolah Dasar.

Rachmadtullah, Reza. (2015). "KEMAMPUAN BERPIKIR KRITIS DAN KONSEP DIRI DENGAN HASIL BELAJAR PENDIDIKAN KEWARGANEGARAAN SISWA KELAS V SEKOLAH DASAR." Jurnal Pendidikan Dasar.

Slavin, Robert E. (2015). “Cooperative Learning in Elementary Schools.” Education 3-13.

Sugiyono. (2016). Metode Penelitian Kuantitatif, Kualitatif,Dan R\&D.

Trianto. (2014). Model Pembelajaran Terpadu. Konsep Strategi Dan Implementasinya Dalam KTSP.

Ulia, Nuhyal. (2014). Peningkatan Pemahaman Konsep Matematika Materi Bangun Datar Dengan Pembelajaran Kooperatif Tipe Group Investigation Dengan Pendekatan Saintifik Di SD. Jurnal Tunas Bangsa.

Wicaksono, Bintang, Laela Sagita, and Wisnu Nugroho. (2017). MODEL PEMBELAJARAN GROUP INVESTIGATION (GI) DAN THINK PAIR SHARE (TPS) TERHADAP KEMAMPUAN BERPIKIR KRITIS. AKSIOMA. 